Scientia Marina 71(3)

September 2007, 505-511, Barcelona (Spain)

ISSN: 0214-8358

\title{
Trophic relationships of the spinner dolphin at Fernando de Noronha Archipelago, SW Atlantic
}

\author{
JOSÉ MARTINS SILVA-JR. ${ }^{1}$, FLÁVIO JOSÉ DE LIMA SILVA², CRISTINA SAZIMA ${ }^{3}$ \\ and IVAN SAZIMA ${ }^{3}$ \\ ${ }^{1}$ Centro Golfinho Rotador, Caixa Postal 49, 53990-000 Fernando de Noronha, PE, Brazil. \\ ${ }^{2}$ Departamento de Ciências Biológicas, Universidade do Estado do Rio Grande do Norte, 59600-970 Mossoró, RN, Brazil. \\ ${ }_{3}^{3}$ Departamento de Zoologia and Museu de História Natural, CP 6109, Universidade Estadual de Campinas, 13083-970 \\ Campinas, SP, Brazil. E-mail: isazima@unicamp.br
}

\begin{abstract}
SUMMARY: We present an overview of predator-prey and other trophic relationships of spinner dolphins (Stenella longirostris) around Fernando de Noronha Archipelago, off northeastern Brazil, with use of original data and a brief review of data published elsewhere. Records were made while snorkelling among the dolphins in daytime. Individual fish pursuit and coordinated school herding were the two hunting tactics recorded. Three small prey types (oceanic squids, fishes, and prawns) were recovered from vomits collected in situ and from stomachs of two stranded dolphins. In their turn, spinners were preyed on by the cookiecutter sharks (Dalatiidae) as evidenced by round and crater-like wounds and circular scars. Additionally, the dolphins were preyed on by large sharks (Lamnidae, Carcharhinidae), as evidenced by crescent-shaped wounds and scars. Unidentified fishes bit fin pieces, as evidenced by variably-shaped marks. On the other hand, dolphins' particulate faeces, vomits and live roundworms were eaten by plankton-feeding fishes. Thus, the trophic role of the spinner dolphins of Fernando de Noronha may be summarised as that of : 1) a predator of small oceanic squids, fishes, and prawns; 2) a prey for the small, piece-eating cookiecutter sharks and other unidentified fishes; 3 ) a prey for large sharks able to kill a dolphin; and 4) a particulate food supplier for plankton-eating fishes.
\end{abstract}

Keywords: Delphinidae, Stenella longirostris, preys, predators, fish associates, coprophagy, trophic role, Fernando de Noronha Archipelago.

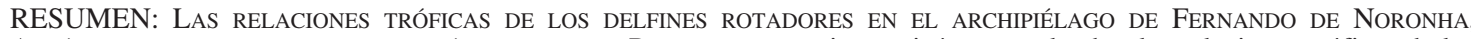
ATLÁNTICO SUDOCCIDENTAL: UNA VISÓN GENERAL. - Presentamos aqui una visón general sobre las relaciones tróficas de los delfines rotadores (Stenella longirostris) en el Archipiélago de Fernando de Noronha, noreste de Brasil. Las observaciones fueron hechas en periodo diurno, en buceo libre. La persecución individual a peces y el cercado coordinado en grupo, fueron las dos técnicas de caza registradas. Tres tipos de presas (calamares, peces y camarones) fueron identificados en vómitos in situ y en los estómagos de dos delfines encallados. Por otro lado, los delfines rotadores fueron depredados por tiburones cigarro (Dalatiidae), como fue evidenciado por heridas en forma de cráter y cicatrices circulares. Los delfines fueron también depredados por tiburones de gran tamaño, como fue evidenciado por mordeduras y cicatrices. Peces no identificados mordieron aletas, como fue evidenciado por las diversas formas de las marcas. Partículas procedentes de las heces y de vómitos así como vermes de los delfines fueron usadas como alimento por peces. El papel trófico de los delfines rotadores puede ser así sintetizado: 1) predador de calamares, peces y camarones; 2) presa de pequeños tiburones y de otros peces que retiran pequeñas porciones de tejido; 3) presa de grandes tiburones; 4) proveedor de partículas alimenticias para varias especies de peces planctófagos.

Palabras clave: Delphinidae, Stenella longirostris, presas, depredadores, peces asociados, coprofagia, función trófica, Archipiélago de Fernando de Noronha. 


\section{INTRODUCTION}

The spinner dolphin (Stenella longirostris, Delphinidae) is one of the best-studied delphinid species, although most of the current knowledge stems from studies on the Pacific populations in Hawaii (review in Norris et al., 1994). Studies on the tropical West Atlantic populations are few and deal mostly with behaviours displayed by surfacing dolphins, data on frequency, and permanence at given sites taken from land-based observation points (Lodi and Fiori, 1987; Silva-Jr. et al., 1996). Recent studies on the underwater behaviour of Atlantic spinners are also scarce (Sazima et al., 2003; Silva-Jr. et al., 2005).

At Fernando de Noronha Archipelago, off northeast Brazil in the tropical west Atlantic, large concentrations of spinner dolphins of up to $c a .2000$ individuals are recorded throughout the year at the cove known as Dolphins' Bay (Silva-Jr. et al., 1996, 2005). At this site the dolphins rest, socialise, mate, nurse, and play-situations that are particularly favourable for underwater records at close quarters, due to the clear waters and the large numbers of spinners (Silva-Jr. et al., 2005). Spinner groups congregate in Dolphin's Bay during the morning and early afternoon, leaving the bay in the afternoon to forage in the open sea (Silva-Jr. et al., 1996).

We present here predator-prey and other trophic relations of Noronha spinners in the waters around the archipelago, seeking a qualitative (and sometimes quantitative) view mostly as perceived from their underwater activity. We present original data on daytime feeding tactics, prey types and wounds caused by predators on Noronha spinners, in addition to reviewing a few data published elsewhere. Since interpretations of shark wounds and shark attack frequency on dolphins are controversial (Cockcroft et al., 1989; Corkeron et al., 1987; Heithaus, 2001; Maldini, 2003), we paid attention to this wound type and hypothesised that small wounds and scars would prevail over larger ones, since small sharks and other fishes are less conspicuous and may be taken by the dolphins as a minor harassment, or even as a prey (e.g. Widder, 1998), whereas large sharks are perceived as dangerous (review in Heithaus, 2001). Additionally, we checked whether wounds caused by cookiecutter sharks (genus Isistius, Dalatiidae) were concentrated on the posterior half of the dolphins' bodies due to the presumed attack behaviour of this shark (Jones, 1971). We emphasise that Noronha spinners play an important role in the oceanic food web around the archipelago.

\section{MATERIAL AND METHODS}

Field records were made in and around Fernando de Noronha Archipelago (03 $50^{\circ} \mathrm{S}, 32^{\circ} 25^{\prime} \mathrm{W}$ ), off northeast Brazil, tropical west Atlantic. Diurnal observational sessions were mostly done in Dolphins' Bay, a 15- to 25-m-deep bay with an area of about $3.5 \mathrm{~km}^{2}$ (Lodi and Fiori, 1987; Silva-Jr. et al., 1996). The bay bottom is a mixture of open sandy areas dotted with patchy reef formations similar to those found in another spinner dolphin resting place, Kealakeakua Bay in Hawaii (Wells and Norris, 1994).

The dolphins' behaviour was observed directly, photographed, and videotaped while snorkelling among the dolphin groups in daytime (Silva-Jr. et al., 1996, 2005). Dolphins were given 1-3 min to become used to the divers before the start of observational sessions of 15-90 min. Focal animal and alloccurrence samplings were used for direct observations in which all occurrences of specified actions (e.g. defecating, hunting) over a given period were recorded (Altmann, 1974). Most records were taken during photo-identification and natural history studies from June 1998 to March 2006 in a total of 227 diving days and $193 \mathrm{~h}$ underwater, but data had been accumulated since September 1990. Additionally, 32 observational sessions totalling $10 \mathrm{~h}$ were conducted at the dolphins' fishing grounds around the archipelago.

Furthermore, we analysed 2223 digitally recorded images of dolphins (according to Würsig and Jefferson, 1990) taken in 26 diving sessions to assess the incidence of shark-bite marks during the period April 2004 to March 2006. From the analyses of 418 photo-identified individuals, we obtained the total number of wounds attributable to sharks on the body of the dolphins, and thus calculated the total numbers and the proportions of two types of shark-bite marks (those due to the small cookiecutters and those due to large sharks). Our figures are underestimates covering only one side of a given dolphin, because the same individual rarely had both sides recorded within an observational session. Dolphin age groups were assessed by proportional lengths: an individual larger than $150 \mathrm{~cm}$ total length, TL, was an adult. We considered calves to be individuals measuring up to $2 / 3$ of a fully grown adult's total length and still suckling occasionally, and juveniles to be individuals that have ceased suckling but are still sexually immature (figures in Silva-Jr. et al., 2005). 
Prey types taken by Noronha spinner dolphins were assessed through analyses of 11 vomits collected underwater, as well as stomach contents of two stranded individuals. In these latter, fish prey consisted of digested remains (bones, otoliths), whereas squids were little digested. Prey remains and photographed records are on file at the Centro Golfinho Rotador in Fernando de Noronha. Voucher samples are at the Museu de História Natural, Universidade Estadual de Campinas (ZUEC).

\section{RESULTS}

Three main and one occasional daytime hunting areas were recorded for the spinner dolphins around Fernando de Noronha Archipelago, all of them outside Dolphins' Bay. The main areas lie over depths of 50-100 m, and coincide with the fishing grounds of the local small fleet (J.M. Silva-Jr., pers. obs.). Targeted preys of the fishing fleet were mostly medium-sized to large oceanic fishes such as tunas and mackerels (Scombridae), rainbow runners and jacks (Carangidae), and dolphinfishes (Coryphaenidae). These fishes are known to prey on schooling small fishes, some of the latter also being preyed on by dolphins, including the spinners (Würsig et al., 1994). The occasional hunting area lies over depths of about $15-20 \mathrm{~m}$.

Two hunting tactics were recorded for the spinner dolphin in daytime, one for individual dolphins and one for grouped ones. The individual hunting tactic recorded $(\mathrm{N}=2)$ was high-speed pursuit of a single fish from a small group of about a dozen (see Neumann and Orams, 2003 for a detailed description and figure of this tactic for Delphinus delphis). The targeted prey fish was the mackerel scad (Decapterus macarellus, Carangidae) $15-20 \mathrm{~cm}$ in total length (TL), both recorded pursuits being successful. The coordinated hunting tactic recorded for groups $(\mathrm{N}=32)$ was carouseling (see Bel'kovich, 1991 for a detailed description of this tactic for Tursiops truncatus, and Neumann and Orams, 2003 for a figure of carouseling in D. delphis). The targeted preys were unidentified fishes, likely scads or flying fishes (Exocoetidae) in large schools composed of hundreds of individuals. On 12 of these hunting occasions, the spinner dolphins were accompanied by yellowfin tunas (Thunnus albacares, Scombridae) foraging for the same prey. Another associate was the pantropical spotted dol-
TABLE 1. - Prey types recovered from two stranded spinner dolphins at Fernando de Noronha Archipelago, SW Atlantic.

\begin{tabular}{lcc}
\hline Prey type & $\mathrm{N}$ & Length $(\mathrm{cm})^{*}$ \\
\hline Squids & 24 & \\
Enoploteuthidae & 23 & \\
Enoploteuthis anapis & 1 & $5-10$ \\
Ommastrephidae & 1 & 8 \\
Hyaloteuthis pelagica & 1 & \\
Fishes & 4 & - \\
Carangidae & 1 & - \\
Exocoetidae & 3 & \\
Prawns & 2 & \\
\hline
\end{tabular}

*Dorsal mantle length (DML)
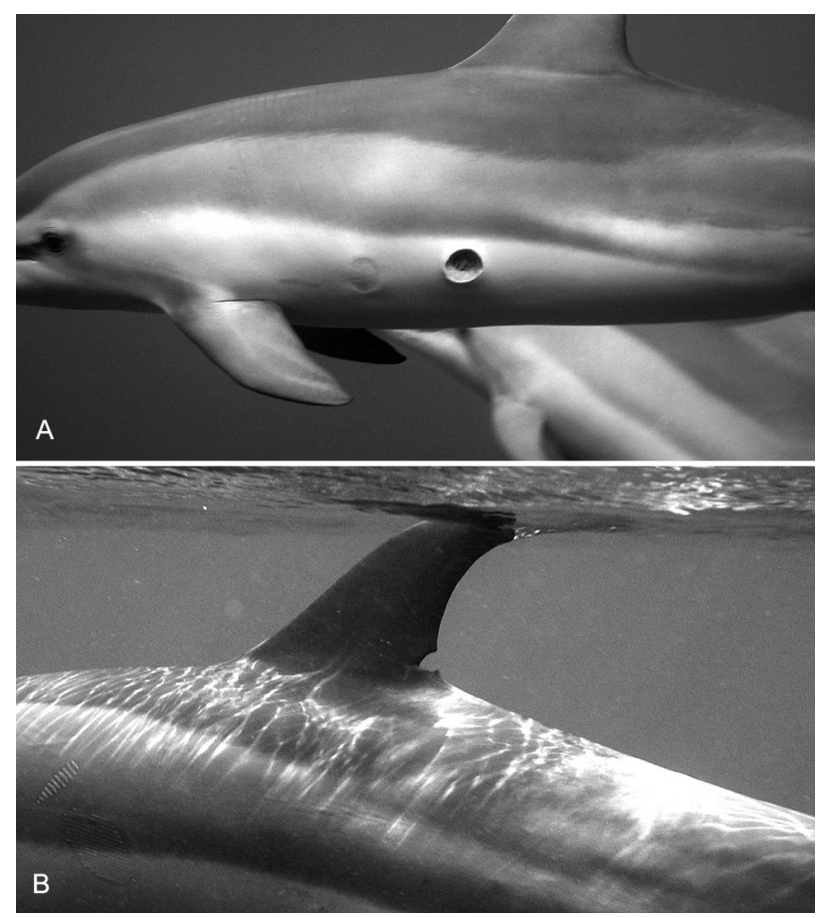

FIG. 1. - Two wound types recorded on spinner dolphins at Fernando de Noronha Archipelago; A, large and fresh crater-like wound attributable to the bite of a cookiecutter shark (Isistius brasiliensis) on the side of an adult dolphin - note an adjacent circular scar left after healing of a wound of this type; B, small anglebordered wound due to a bite of unidentified fish species (likely a small shark or perhaps an oceanic puffer, Lagocephalus lagocephalus) at the base of dorsal fin of an adult spinner.

phin (Stenella attenuata). The individual pursuit was en route to open waters, and the carouseling was at the spinner dolphins' hunting areas.

The prey remains recovered from 11 spinner dolphin vomits were beaks and partially digested arms and mantle pieces of squids. The beaks were identified as belonging to Ommastrephidae and Cranchiidae. Prey types recovered from the two stranded dolphins were squids, fishes, and prawns (Table 1). Summing up the data obtained from direct observations underwater, analyses of vomit remains and stomach contents, food recorded for the spinner 
TABLE 2. - Number and relative proportion (\%) of body wounds and scars recorded in 418 photographic records of spinner dolphins at Fernando de Noronha Archipelago for three age classes over a period of 24 months (April 2004-March 2006).

\begin{tabular}{lccc}
\hline Wounds and scars (per predator type) & calves (N=5) & $\begin{array}{c}\text { Spinner dolphin classes } \\
\text { juveniles (N=12) }\end{array}$ & adults (N=401) \\
\hline $\begin{array}{l}\text { Cookiecutter sharks (Isistius spp.) } \\
\text { Large sharks (Lamnidae, Carcharhinidae) }\end{array}$ & $\begin{array}{c}10(100 \%) \\
0\end{array}$ & $\begin{array}{c}34(97.14 \%) \\
1(2.86 \%)\end{array}$ & $\begin{array}{c}1383(96.24 \%) \\
54(3.76 \%)\end{array}$ \\
\hline
\end{tabular}

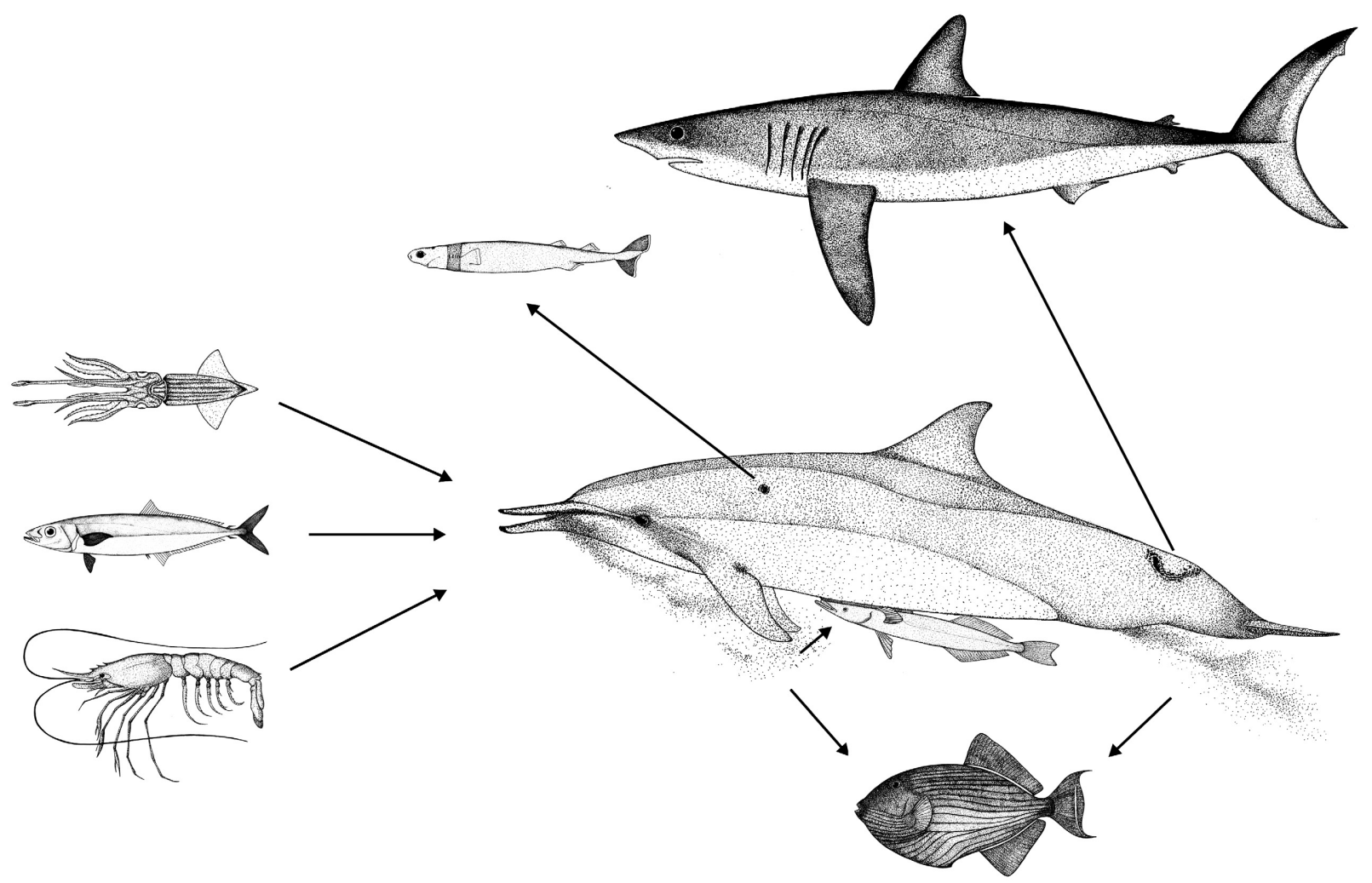

FIG. 2. - Predator-prey and other trophic relationships of the spinner dolphin at Fernando de Noronha Archipelago. The dolphin preys on small oceanic squids, fishes and prawns. The small cookiecutter shark feeds on hemispheroid pieces of tissue cut off from a dolphin's body. Large sharks such as the mako are able to kill a dolphin. Dolphins' vomits and faeces are picked off by plankton-eating fishes such as the black durgon. Whalesuckers attached to a dolphin feed on its wastes and sloughed skin, besides cleaning the cetacean from parasites and diseased tissue. Not drawn to scale.

dolphin at Noronha included small oceanic squids, fishes and prawns.

Analyses of the photographic records yielded two main types of body wounds and scars (Fig. 1A, Table 2). The first type were roundish and craterlike, indicating that the dolphins had been heavily preyed on by cookiecutter sharks (Isistius sp.) (Fig. 1A). We counted 998 wounds and scars due to cookiecutter shark bites on the posterior half of the dolphins' bodies, and 429 such wounds and scars on the anterior half. In all observational sessions $(\mathrm{N}=26)$ we found more wounds on the posterior half than on the anterior one (binomial test, $\mathrm{N}=26, \mathrm{k}=26, \mathrm{P}$ $<0.0001$ ). During incidental observations of a large dolphin group of $c a .500$ individuals in June 2006, we recorded a cookiecutter wound on the head of two individuals (one of these on the melon area), an apparently rare occurrence since it was unrecorded in our large two-year sample.

The second type of wounds and scars were crescent-like, indicating that spinner dolphins had been preyed on by large sharks (Lamnidae and Carcharhinidae) (Table 2, Fig 2). A large fresh wound recorded in a healthy dolphin female $c a .170$ $\mathrm{cm}$ TL accompanied by a calf was identified as a bite of the upper jaw of a mako shark (Isurus oxyrinchus, Lamnidae) estimated to be of $c a .230$ $\mathrm{cm}$ TL, based on the wound pattern and width (O.B.F. Gadig, pers. comm.). From an elevated place on the shore we recorded one adult spinner of 
ca. $160 \mathrm{~cm}$ TL being killed by three unidentified carcharhinid sharks of $c a$. 150-200 cm TL.

Additionally, cutting, nipping, and otherwise tissue-tearing fish species preyed on pieces of dolphins' fins, as evidenced by variably-shaped marks (Figs. 1B).

Besides squid and fish remains, live roundworms (Anisakis sp., Anisakidae) were voided along with dolphins' vomits and picked off by fishes that feed on both vomits and particulate faeces. Several reef fish species feed on the faeces and vomits of these cetaceans (review in Sazima et al., 2006). The black durgon (Melichthys niger) was the only species recorded to be regularly associated with the spinner dolphins at Dolphins' Bay in all our observation sessions.

A summary of the predator-prey and other trophic relationships of spinner dolphins of Fernando de Noronha Archipelago (as perceived mostly from underwater observations) is shown in Fig. 2.

\section{DISCUSSION}

The two hunting tactics we observed for the Fernando de Noronha spinners are recorded in detail for Tursiops truncatus (Bel'kovich, 1991) and Delphinus delphis (Neumann and Orams, 2003), and are probably common tactics for other delphinids as well.

Ommastrephidae, Cranchiidae and Enoploteuthidae are oceanic squids and a common component in the diet of several delphinids and other cetaceans (review in Clarke, 1996), and the same applies to fish species of Exocoetidae and Carangidae (e.g. Barros and Clarke, 2002). However fragmentary and incomplete the results we have on the food of Fernando de Noronha spinner dolphins, these are the first ones documented by voucher specimens. The diet of Stenella attenuata is known to some detail (review in Wang et al., 2003), and does not differ much from that recorded for $S$. longirostris (Würsig et al., 1994), Delphinus delphis (Neumann and Orams, 2003) and most other small to mediumsized delphinid species (Barros and Clarke, 2002).

Most of the roundish and crater-like wounds and scars we recorded on Fernando de Noronha spinner dolphins are attributable to the cookiecutter shark (Isistius brasiliensis), since the large-toothed cookiecutter shark (I. plutodus) seems much rarer than the former species and its bites appear to be oval, elongate and larger (Pérez-Zayas et al., 2002). The preva- lence of cookiecutter shark bites on the posterior half of a dolphin body may be related to this shark preying tactic, which supposedly includes mimicking luminescent squids (Widder, 1998) and a frontal approach (Jones, 1971). While approached by its potential prey, the shark would have room to dash at a veering off dolphin and bite it on the posterior half of the body after the cetacean rejected it as food and/or recognised it as a potential harassment.

Since the cookiecutter shark takes a tissue piece without killing its prey, it is sometimes regarded as a parasite (e.g., Jones, 1971). The diameter of the hemispheroid pieces of skin and muscle tissue bitten off from a dolphin or a fish by a cookiecutter shark is $c a .2-6 \mathrm{~cm}$, and its mass is $c a .5-20 \mathrm{~g}$ (Jones, 1971; IS, pers. obs.). Since an adult spinner dolphin weighs $45-75 \mathrm{~kg}$ (Perrin and Gilpatrick, 1994), it would loose $c a$. $0.01-0.03 \%$ of its body mass on each successful cookiecutter attack. This proportion is negligible and, moreover, the piece bitten off is replaced by skin, connective and muscle tissues. However, we have observed that some dolphin individuals develop an ulcerative condition apparently associated with such wounds. The ulcer develops under the skin and may extend to an area up to 30 times larger than the original wound. It eventually heals after an extended period and leaves a characteristic scar. If the ulcer is an infection, as it indeed appears, then a wound due to a cookiecutter shark occasionally has a more deleterious effect than simply a little loss of tissue that will heal with time.

Nips and variably-shaped marks mostly on dorsal fins of spinner dolphins are likely due to attacks of small sharks and perhaps the oceanic puffer (Lagocephalus lagocephalus) as well. This large pelagic puffer — of up to $60 \mathrm{~cm}$ TL—feeds on squids and prawns (Tortonese, 1986), the same prey type as that favoured by spinner dolphins. Thus, spinners and puffers may meet on common diurnal feeding grounds, where the latter may take the chance to nip at a dolphin fin. Puffer species are already recorded as fin-biters of larger fish for food (Gerking, 1994). However, at least some of the round and semicircular pieces missing from spinner dolphins' fins may be due to bites by cookiecutter sharks (Isistius). A similar wound cut through the trailing edge of the tail of a swordfish (Xiphias gladius, Xiphiidae) is illustrated in Jones (1971).

The large fresh wound recorded in a healthy dolphin female left by a bite of the mako shark (Isurus oxyrinchus) strengthens the suggestion that spinner 
dolphins are preyed on by this large oceanic shark (Heithaus, 2001). The greater vulnerability of nursing females to shark attacks is already emphasised by some authors (e.g. Corkeron et al., 1987; Cockcroft et al., 1989) and our single record adds to this statement. The absence of wounds and scars attributable to large sharks on calves and juveniles is likely due to the fact that this wound type would be fatal to a small dolphin (Cockcroft et al., 1989). We favour the view of Cockcroft et al. (1989) and Maldini (2003) on attacks of large sharks on dolphins: wounded and scarred individuals are survivors of missed, potentially fatal attacks. Our view seems strengthened by the very small proportion of such wound and scar types in our large adult spinner dolphin sample. Additionally, in open waters there are no retreats available such as those that dolphins may use in coastal waters (Heithaus, 2001).

Our observation of roundworms from the spinner dolphins' vomits ingested by reef fishes seems to be the first record of fishes regularly eating live internal parasites from a cetacean. Thus, an additional food type is supplied by spinner dolphins to plankton-eating fishes, besides particles in faeces and vomits (Sazima et al., 2003, 2006).

As emphasised by Trites (2002), there is little empirical evidence and few observational studies to evaluate the predator-prey relationships of cetaceans and other marine mammals in the diverse ecosystems they inhabit. We found that spinner dolphins play an important role in the oceanic food web around Fernando de Noronha, which may be summarised as that of: 1) a predator of small oceanic squids, fishes, and prawns; 2) a prey for the small, piece-eating cookiecutter sharks and other unidentified fishes; 3 ) a prey for large sharks able to kill a dolphin; and 4) a particulate food supplier for plankton-eating fishes. This latter function adds an ecological role to those already recorded for cetaceans, as pointed out by Silva-Jr. et al. (2005).

\section{ACKNOWLEDGEMENTS}

We thank Teodoro Vaske Jr. for the kind identification of squid and fish prey; Otto B. F. Gadig for the careful analysis of the mako shark wound; Lawrence Wahba for video-taping the dolphin female wounded by a mako shark; Paulo R. Guimarães Jr. for statistical advice; the AVINA, Banco do Brasil, CNPq, FAPESP, and PETRO-
BRAS for essential financial support; and the IBAMA for issuing permits to study spinner dolphins and reef fishes in the Marine National Park of Fernando de Noronha, and for providing logistic support.

\section{REFERENCES}

Altmann, J. - 1974. Observational study of behavior: sampling methods. Behaviour, 49: 227-265.

Barros, N.B. and M.R. Clarke. - 2002. Diet. In: W.F. Perrin, B. Würsig and J.G.M. Thewissen (eds.), Encyclopedia of marine mammals, pp. 323-327. Academic Press, London.

Bel'kovich, V.M. (ed.). - 1991. Herd structure, hunting, and play: bottlenose dolphins in the Black Sea. In: K. Pryor and K.S. Norris (eds.), Dolphin societies: discoveries and puzzles, pp. 17-77. University of California Press, Berkeley.

Clarke, M.R. - 1996. Cephalopods as prey. III Cetaceans. Phil. Trans. R. Soc. Lond., 351: 1053-1065.

Cockcroft, V.G., G. Cliff and G.J.B. Ross. - 1989. Shark predation on Indian Ocean bottlenose dolphins Tursiops truncatus off Natal, South Africa. S. Afr. J. Zool., 24: 305-310.

Corkeron, P.J., R.J. Morris and M.M. Bryden. - 1987. Interactions between bottlenose dolphins and sharks in Moreton Bay, Queensland. Aquat. Mam., 13: 109-113.

Gerking, S.D. - 1994. Feeding ecology of fish. Academic Press, London.

Heithaus, M.R. - 2001. Predator-prey and competitive interactions between sharks (order Selachii) and dolphins (suborder Odontoceti): a review. J. Zool. (London), 253: 53-68.

Jones, E.C. - 1971. Isistius brasiliensis, a squaloid shark, the probable cause of crater wounds on fishes and cetaceans. Fish. Bull., 69: 791-798.

Lodi, L. and B. Fiori. - 1987. Observações sobre o comportamento do golfinho-rotador; Stenella longirostris (Cetacea, Delphinidae) na Ilha de Fernando de Noronha - Brasil. In: Anais da 2a Reunião de Trabalho de Especialistas em Mamíferos Aquáticos da América do Sul, Rio de Janeiro, Brasil: 60-68.

Maldini, D. - 2003. Evidence of predation by a tiger shark (Galeocerdo cuvier) on a spotted dolphin (Stenella attenuata) off O'ahu, Hawai'i. Aquat. Mam., 29: 84-87.

Neumann, D.R. and M.B. Orams. - 2003. Feeding behaviours of short-beaked common dolphins, Delphinus delphis, in New Zealand. Aquat. Mam., 29: 137-149.

Norris, K.S., B. Würsig, R.S. Wells and M. Würsig (eds.) - 1994. The Hawailan spinner dolphin. University of California Press, Berkeley.

Pérez-Zayas, J., A. Mignucci-Giannoni, G. Toyos-González, R. Rosario-Delestre and E. Williams. - 2002. Incidental predation by a largetooth cookiecutter shark on a Cuvier's beaked whale in Puerto Rico. Aquat. Mam., 28: 308-311.

Perrin, W.F. and J.W. Gilpatrick, Jr. - 1994. Spinner dolphin. In: S.H. Ridgway and R. Harrison (eds.), Handbook of marine mammals, Vol. 5, pp. 99-128. Academic Press, London.

Sazima, I., C. Sazima and J.M. Silva-Jr. - 2003. The cetacean offal connection: feces and vomits of spinner dolphins as a food source for reef fishes. Bull. Mar. Sci., 72: 151-160.

Sazima, I., C. Sazima and J.M. Silva-Jr. - 2006. Fishes associated with spinner dolphins at Fernando de Noronha Archipelago, tropical west Atlantic: an update and overview. Neotrop. Ichthyol., 4: 451-455.

Silva-Jr., J.M., F.J.L. Silva and J.A. Pereira. - 1996. O comportamento do golfinho rotador em F. de Noronha. Anais 14 Encontro Anual de Etologia, Uberlândia, MG, Brasil: 251-262.

Silva-Jr., J.M., F.J.L. Silva and I. Sazima. - 2005. Rest, nurture, sex, release, and play: diurnal underwater behaviour of the spinner dolphin at Fernando de Noronha Archipelago, SW Atlantic. Aqua, J. Ichthyol. Aquat. Biol., 9: 161-176.

Tortonese, E. 1986. - Tetraodontidae (including Canthigasteridae). In: P.J.P. Whitehead, M.L. Bauchot, J.C. Hureau, J. Nielsen and 
E. Tortonese (eds.), Fishes of the North-eastern Atlantic and the Mediterranean, vol. III, pp. 1341-1345. Unesco, Paris.

Trites, A.W. - 2002. Predator-prey relationships. In: W.F. Perrin, B. Würsig and J.G.M. Thewissen (eds.), Encyclopedia of marine mammals, pp. 994-997. Academic Press, London.

Wang, M.C., W.A. Walker, K.T. Shao and L.S. Chou. - 2003. Feeding habits of the pantropical spotted dolphin, Stenella attenuata, of the eastern coast of Taiwan. Zool. Stud., 42: 368-378

Wells, R.S. and K.S. Norris. - 1994. The island habitat. In: K.S. Norris, B. Würsig, R.S. Wells and M. Würsig (eds.), The Hawaiian spinner dolphin, pp. 31-53. University of California Press, Berkeley.

Widder, E.A. - 1998. A predatory use of counterillumination by the squaloid shark, Isistius brasiliensis. Environ. Biol. Fish., 53 267-273.
Würsig, B. and T.A. Jefferson. - 1990. Methods of photo-identification for small cetaceans. In: P.S. Hammond, S.A. Mizroch and G.P. Donovan (eds.), Individual recognition of cetaceans: use of photo-identification and other techniques to estimate population parameters, pp. 43-52. International Whaling Commission, Cambridge.

Würsig, B., R.S. Wells and K.S. Norris. - 1994. Food and feeding. In: K.S. Norris, B. Würsig, R.S. Wells and M. Würsig (eds.), The Hawaiian spinner dolphin, pp. 216-231. University of California Press, Berkeley.

Scient. ed.: M.P. Olivar.

Received November 30, 2006. Accepted May 9, 2007.

Published online July 9, 2007. 